\title{
Navike, znanje i stavovi o spolnosti adolescenata Brodsko-posavske županije
}

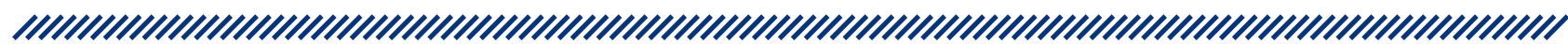

1,2 Valentina Koporčić

2,3 Željko Jovanović

1 Opća bolnica Pula

2 Sveučilište Jurja Dobrile u Puli, Medicinski fakultet, studij sestrinstva

3 Sveučilište u Rijeci, Fakultet zdravstvenih studija

\section{Sažetak}

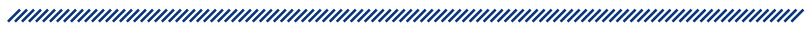

Cilj rada: Adolescencija je razvojna faza tijekom koje pojedinci počinju učvršćivati osjećaj identiteta, obilježen autonomnim funkcioniranjem koje će dovesti do neovisnog života uz održavanje sigurnih veza s obitelji, vršnjacima i širom zajednicom te spolnog sazrijevanja. Cilj je ovog rada ispitati i usporediti znanje, stavove i navike o spolnosti adolescenata te utvrditi postoje li razlike između učenika medicinske škole i gimnazije.

Metode rada: Analiza je provedena anonimnim anketnim upitnikom od 27 pitanja općeg karaktera te pitanjima navika, ponašanja, znanja i stavova povezanih sa spolnošću. $U$ istraživanje su uključeni učenici Srednje medicinske škole i Gimnazije "Matija Mesić” u Slavonskom Brodu u dobi od 17 do 20 godina. Sudjelovalo je 100 učenika; od toga ukupno 72 djevojke i 28 mladića.

Rezultati: Dobiveni podaci pokazuju da je $59 \%$ anketiranih stupilo u spolni odnos. Tek $17 \%$ ispitanika pokazalo je visoku razinu znanja koje se odnosi na spolnost i prevenciju rizičnih ponašanja. Većina ispitanika (65\%) smatra da bi besplatni kontraceptivi smanjili broj neže- ljenih trudnoća i spolno prenosivih bolesti, dok gotovo svi (91\%) smatraju da je zdravstveni odgoj potreban u školama.

Zaključak: Većina ispitanika stupila je u spolne odnose, češće oni iz medicinske škole, a najčešći je razlog prvog stupanja u spolni odnos ljubav. Gotovo svi ispitanici upotrebljavaju kontracepciju. Znanje ispitanika o spolnosti, posebno gimnazijalaca, na nezadovoljavajućoj je razini. Ispitanice imaju znatno jasnije stavove protiv abortusa od muških ispitanika. Većina ispitanika želi zdravstveni odgoj u školama.

Ključne riječi: adolescenti, navike, znanja, stavovi, spolnost

Datum primitka: 16.11.2021.

Datum prihvaćanja: 15.12.2021.

https://doi.org/10.24141/1/8/1/9

Adresa za dopisivanje:

A: Sveučilište u Rijeci, Fakultet zdravstvenih studija, Katedra za temeljne medicinske znanosti, Viktora Cara Emina 5, Rijeka

E-mail: zeljko.jovanovic@uniri.hr M: 098329495 


\section{Uvod}

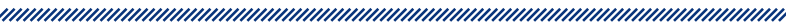

Adolescencija je razvojna faza tijekom koje pojedinci počinju učvršćivati osjećaj identiteta, obilježen autonomnim funkcioniranjem koje će dovesti do neovisnog života uz održavanje sigurnih veza s obitelji, vršnjacima i širom zajednicom. Objavljena istraživanja i teorija o adolescenciji prikladno predstavljaju ključnu važnost razumijevanja ove faze u životu u brojnim stručnim i znanstvenim časopisima posvećenima upravo ovoj životnoj fazi, s više od 500000 članaka objavljenih u posljednjem desetljeću. Širina istraživanja nije samo odraz izvanrednog rasta koji se događa tijekom ovog razvojnog razdoblja, već i odraz promjena perspektiva o tome kako karakterizirati adolescenciju. Napredak u metodologiji istraživanja i promjene u sociološko-povijesnom kontekstu u kojem se odvija razvoj stvorili su potrebu za redefiniranjem obrazaca razvoja adolescenta, a napredak u mjerama analize funkcioniranja mozga i fizioloških procesa dao je informacije o razvojnim promjenama na diskretnijoj razini analize. Razlike u socijalnim i ekološkim iskustvima današnjih adolescenata stvorile su i nove kontekste u kojima se odvijaju razvojni prijelazi ove životne faze. ${ }^{1}$

Adolescenti 21. stoljeća tehnološki su pametniji od prethodnih generacija i žive u svijetu obilježenom sve većom kulturnom i etničkom raznolikošću. Za razliku od povijesnih i tradicionalnijih pristupa razvoju, koji se temelje na linearnim modelima postizanja razvojnih zadataka, današnji okvir definiraju dvije značajke. Prvo, naglašava integrativni pristup koji se fokusira na interakciju i uzajamnost razvoja u različitim domenama funkcioniranja. Na primjer, na biološke promjene povezane s adolescencijom može utjecati obiteljsko okruženje, a fizička manifestacija tih promjena može utjecati na prirodu obiteljskih odnosa. Drugo, ovaj okvir priznaje heterogenost $u$ adolescenciji. Brojni čimbenici, koje pojedinci jedinstveno doživljavaju tijekom razvoja, mogu utjecati na put i vrijeme postizanja razvojnih prekretnica. $^{2}$

Spolno ponašanje adolescenata važno je zbog sve većeg broja seksualno aktivnih adolescenata u svijetu. lako je započinjanje seksualne aktivnosti dio normalnog ponašanja i razvoja, također može biti povezano s negativnim ishodima ako seksualno ponašanje uključuje sudjelovanje u seksualnoj aktivnosti u preranoj dobi ili bez odgovarajuće pažnje posvećene rizicima. ${ }^{3}$
Tinejdžeri i mladi mogu se suočiti s mnogim rizicima za seksualno i reproduktivno zdravlje koji proizlaze iz ranih, nezaštićenih ili neželjenih seksualnih aktivnosti. Na primjer, rano započinjanje seksualnih aktivnosti povećava vrijeme u kojem su adolescenti izloženi riziku od spolno prenosivih infekcija ili nenamjerne trudnoće. lako ne postoji univerzalna definicija ranog započinjanja seksualne aktivnosti, često se klasificira kao spolni odnos tijekom početnih srednjoškolskih godina ili seksualni odnos prije dobi zakonskog pristanka., ${ }^{4,5}$ Za mnoge adolescente seksualna aktivnost može započeti ranije nego što je dopušteno zakonom; na primjer, u SAD-u je prijavljeno da se $62 \%$ učenika bavilo seksualnom aktivnošću prije napuštanja škole, a u mnogim slučajevima mladi ljudi mogu započeti seksualne odnose prije navršene 14. godine. Mogu postojati povezani rizici rane trudnoće, na primjer ako adolescenti dobro ne razumiju kontracepciju. ${ }^{6} \mathrm{Na}$ seksualno ponašanje mogu utjecati mnogi fiziološki čimbenici, uz kulturne i socijalne pritiske koji se mogu brzo mijenjati od generacije do generacije. Razumijevanje fizioloških utjecaja koji potiču adolescentsku seksualnu aktivnost, poput hormonskih, kemijskih i neuroloških reakcija i promjena, može pomoći u informiranju intervencija koje će pružiti potporu adolescentima u donošenju odgovarajućih izbora povezanih sa seksualnim ponašanjem. Istraživanje prirode ovih fizioloških procesa i s njima povezanih posljedica ključno je za osmišljavanje učinkovitih odgovora kako bi se udovoljilo potrebama spolnog i reproduktivnog zdravlja adolescenata i može pomoći u zaštiti njihovih prava u odnosu na njihov izbor. Poboljšano razumijevanje čimbenika koji adolescente mogu predisponirati na određeno ponašanje može pomoći ne samo informiranju adolescenata nego i onih koji su uključeni u njihovu skrb. ${ }^{6}$ Tinejdžerska trudnoća jedan je od rizika ranog stupanja u spolne odnose. Čimbenici rizika utječu na pojavu tinejdžerske trudnoće iz različitih konteksta. Brojne studije identificirale su sociodemografske čimbenike rizika, poput niskoga obiteljskog socioekonomskog statusa, niskoga obrazovnog statusa majke i samohrane obiteljske strukture, koji su povezani s povećanom vjerojatnošću tinejdžerske trudnoće. Postoje neki dokazi koji upućuju na to da se međugeneracijski prijenos tinejdžerskih trudnoća događa između majki tinejdžerki i njihovih kćeri. Slično tome, ponašanje starijih sestara vjerojatno utječe na stavove i ponašanje mlađih sestara povezanih uz trudnoću i porod. Brojne studije također sugeriraju da su tinejdžerske trudnoće povezane s problemima u ponašanju u djetinjstvu i asocijalnom ponašanju adolescenata, možda zbog zajedničkih čimbenika rizika iz ranog djetinjstva. lako 
postoje dokazi o zajedničkim rizicima koje imaju sve mlade žene koje postaju tinejdžerice, postoje i dokazi o jedinstvenim razlikama u rizicima na temelju rase $\mathrm{i}$ etničke pripadnosti, što upućuje na to da tinejdžerske majke nisu homogena skupina. ${ }^{7,8}$

Proučavanje tinejdžerskih trudnoća kao ishoda povezanog s akumulacijom i interakcijom čimbenika rizika iz djetinjstva i adolescenata omogućuje istraživačima da bolje predviđaju koje su mlade žene pod najvećim rizikom za tinejdžersku trudnoću i porod, s krajnjim ciljem stvaranja učinkovitijih intervencija za smanjenje tih ishoda. Proveden je niz dobro osmišljenih studija koje su procjenjivale razvojne čimbenike rizika povezane s tinejdžerskim rađanjem, u kojima su identificirani mnogi važni čimbenici rizika za tinejdžersku trudnoću i rađanje djece. ${ }^{9}$ lako stope tinejdžerske trudnoće mogu padati u nekim zemljama sa srednjim i visokim dohotkom, ${ }^{5}$ rana seksualna aktivnost i trudnoća još uvijek prevladavaju u drugim područjima i kulturama, a mogu biti povezane s povećanim morbiditetom i smrtnošću. ${ }^{3}$ Poticanje primjerenih stavova o seksualnom ponašanju i aktivnostima tijekom adolescencije može pomoći osigurati razumijevanje kontracepcije, namjeru trudnoće i smanjenje ciklusa oduzetosti povezanog s trudnoćom u mladih ljudi mlađih od 18 godina. Promicanje zdravog seksualnog ponašanja može pomoći u smanjenju ovih rizika i daljnjih negativnih ishoda, poput spolno prenosivih infekcija. ${ }^{10-13}$

Ciljevi ovog istraživanja bili su:

- ispitati navike, znanje i stavove o spolnosti adolescenata

- utvrditi postoji li razlika u znanju, navikama i stavovima o spolnosti između učenika zdravstvene škole u odnosu na učenike nezdravstvene škole

- utvrditi utjecaj znanja adolescenata na njihovo ponašanje i stavove o spolnosti.

\section{Ispitanici i metode}

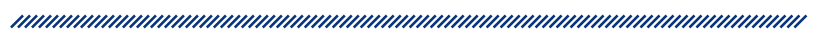

Provedena je presječna studija. $U$ istraživanju je sudjelovalo 100 ispitanika u dobi od 17 do 20 godina, mladići i djevojke završnih razreda dviju škola iz Slavonskog Broda, Srednje medicinske škole Slavonski Brod te Gimnazije „Matija Mesić". Ispitivanje je provedeno dobrovolj- nom anonimnom anketom koja je preuzeta s privolom, sastavljena iz već provedenog istraživanja „Spolno ponašanje adolescenata, njihova informiranost i mišljenje o seksualnosti" (Petani i Vulin 2018). ${ }^{14}$ Sadržavalo je 27 pitanja od kojih su uvodna pitanja o općim podacima te tri domene; pitanja o njihovu znanju, navikama te stavovima o spolnosti koja su izmiješana. Ispitanici su zaokruživali odgovor koji smatraju da ih najbolje opisuje. Predgovor u upitniku dao je do znanja sudionicima da je anonimnost sudionika u istraživanju zajamčena te da je istraživanje u skladu s Općom uredbom o zaštiti podataka (engl. General Dana Protection Regulation - GDPR). Rješavanjem upitnika sudionici su dali suglasnost da se podaci iz upitnika obrađuju u svrhu istraživanja.

Kategorijski podaci predstavljeni su apsolutnim i relativnim frekvencijama. Normalnost raspodjele numeričkih varijabli je testirana Kolmogorov-Smirnovljevim testom. Razlike kategorijskih varijabli testirane su hikvadrat testom. Sve su vrijednosti p dvostrane. ${ }^{15}$ Razina značajnosti postavljena je na Alpha $=0,05$. Za statističku analizu primijenjen je statistički program SPSS (inačica 16.0, SPSS Inc., Chicago, IL, SAD).

\section{Rezultati}

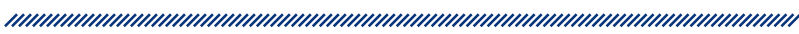

U istraživanju je sudjelovalo 100 ispitanika srednjoškolaca iz Slavonskog Broda. Većina ispitanika bila je ženskog spola (60\%), u dobi 17 do 19 godina (tablica 1). Od

\section{Tablica 1. Osnovna obilježja ispitanika}

\begin{tabular}{|c|c|c|}
\hline & & N (\%) \\
\hline Spol & M & $40(40,4)$ \\
\hline & 17 godina & $60(60,0)$ \\
\hline Dob & 18 godina & $46(46,5)$ \\
\hline & 19 godina & $24(24,2)$ \\
\hline Škola & gimnazija & $50(50,5)$ \\
\hline & medicinska škola & $50(50,0)$ \\
\hline
\end{tabular}




\begin{tabular}{|c|c|c|}
\hline \multicolumn{2}{|l|}{ NAVIKE } & $\mathrm{N}(\%)$ \\
\hline \multirow{2}{*}{$\begin{array}{l}\text { 1. Jesi li ikad imao/la spolni } \\
\text { odnos? }\end{array}$} & $\mathrm{da}$ & $59(59,0)$ \\
\hline & ne & $41(41,0)$ \\
\hline \multirow{5}{*}{$\begin{array}{l}\text { 2. Razlog stupanja u spolni } \\
\text { odnos bio je: }\end{array}$} & ljubav & $37(62,7)$ \\
\hline & $\begin{array}{c}\text { utjecaj } \\
\text { vršnjaka }\end{array}$ & $1(1,7)$ \\
\hline & droga/alkohol & $3(5,1)$ \\
\hline & znatiželja & $17(28,8)$ \\
\hline & $\begin{array}{l}\text { nagovor } \\
\text { partnera }\end{array}$ & $1(1,7)$ \\
\hline \multirow{2}{*}{ 3. Imaš li stalnog partnera? } & $\mathrm{da}$ & $34(57,6)$ \\
\hline & ne & $25(42,4)$ \\
\hline \multirow{2}{*}{$\begin{array}{l}\text { 4. Jesi li ikad imao/la „partnera } \\
\text { za jednu noć”? }\end{array}$} & $\mathrm{da}$ & $14(23,7)$ \\
\hline & ne & $45(76,3)$ \\
\hline \multirow{2}{*}{$\begin{array}{l}\text { 5. Jesi li upoznat/a s } \\
\text { dosadašnjim spolnim životom } \\
\text { svojeg partnera? }\end{array}$} & da & $43(72,9)$ \\
\hline & ne & $16(27,1)$ \\
\hline \multirow{5}{*}{$\begin{array}{l}\text { 6. Koje vrste kontracepcije } \\
\text { upotrebljavate? }\end{array}$} & ne koristim & $4(6,8)$ \\
\hline & prezervativ & $44(74,6)$ \\
\hline & pilule & $4(6,8)$ \\
\hline & $\begin{array}{l}\text { prekinuti } \\
\text { snošaj }\end{array}$ & $3(5,1)$ \\
\hline & više metoda & $4(6,8)$ \\
\hline \multirow{2}{*}{$\begin{array}{l}\text { 7. Pitanje za djevojke:- Jesi li do } \\
\text { sada upotrebljavala pilule za } \\
\text { dan poslije? }\end{array}$} & da & $4(10,5)$ \\
\hline & ne & $34(89,5)$ \\
\hline \multirow{3}{*}{$\begin{array}{l}\text { 8. Razgovaraš li s nekim o } \\
\text { temama povezanima sa } \\
\text { spolnim odnosima? }\end{array}$} & da & $63(63,0)$ \\
\hline & informiram se & $28(28,0)$ \\
\hline & ne & $9(9,0)$ \\
\hline \multirow{5}{*}{$\begin{array}{l}\text { 9. Ako je tvoj odgovor na } \\
\text { prethodno pitanje „da”, s kim } \\
\text { razgovaraš o tim temama? }\end{array}$} & roditelji & $11(17,5)$ \\
\hline & brat/sestra & $10(15,9)$ \\
\hline & prijatelji & $30(47,6)$ \\
\hline & liječnik & $0(0,0)$ \\
\hline & partner & $12(19,0)$ \\
\hline \multirow{2}{*}{$\begin{array}{l}\text { 10. Pitanje za djevojke: Jesi li do } \\
\text { sada bila na ginekološkom } \\
\text { pregledu? }\end{array}$} & da & $25(41,7)$ \\
\hline & ne & $35(58,3)$ \\
\hline
\end{tabular}

ukupnog broja 59 ih je već stupilo u spolni odnos. Kao glavni razlog stupanja u prvi spolni odnos ističu ljubav $(62,7 \%)$, a potom znatiželju ( $28,8 \%)$. Među ispitanicima koji su prakticirali spolne odnose, 57,6 \% ima stalnog partnera, a $23,7 \%$ navodi kako su imali partnere za jednu noć. Većina tih ispitanika (72,9\%) naglašava kako je upoznata s dosadašnjim spolnim životom partnera, kao najčešće korišteni oblik kontracepcije ističu prezervativ (74,6\%), a većina ispitanika (63\%) razgovara s nekim o spolnim odnosima, dok ih se trećina $(28 \%)$ informira putem interneta i knjiga povezanih s tom temom. Među djevojkama koje su stupile u spolni odnos samo ih je $10,5 \%$ upotrebljavalo pilule za dan poslije. Na ginekološkom pregledu nikad nije bilo 58,3 \% djevojaka (tablica 2). Tek $17 \%$ ispitanika imalo je sve točne odgovore iz područja spolnog zdravlja, a $80 \%$ ih je bilo na više od polovice točnih odgovora. Pitanje na koje su svi ispitanici točno odgovorili ticalo se pouzdanosti prekinutog snošaja kao metode kontracepcije, a potom slijedi pitanje o utjecaju hormonske terapije za prevenciju spolnih bolesti (93\%). Pitanje na koje je većina ispitanika odgovorila netočno ( $40 \%$ točnih odgovora) ticalo se načina prenošenja hepatitisa B (tablica 3). Većina ispitanica

\begin{tabular}{|c|c|c|}
\hline \multicolumn{2}{|l|}{ ZNANJE } & $\mathrm{N}(\%)$ \\
\hline \multirow{2}{*}{$\begin{array}{l}\text { 1. Štiti li hormonska } \\
\text { kontracepcija od spolno } \\
\text { prenosivih bolesti? }\end{array}$} & točno & $93(93,0)$ \\
\hline & netočno & $7(7,0)$ \\
\hline \multirow{2}{*}{$\begin{array}{l}\text { 2. Štiti li prezervativ } 100 \% \text { od } \\
\text { spolno prenosivih bolesti? }\end{array}$} & točno & $87(87,0)$ \\
\hline & netočno & $13(13,0)$ \\
\hline \multirow{2}{*}{ 3. HIV se može prenijeti: } & točno & $76(76,0)$ \\
\hline & netočno & $24(24,0)$ \\
\hline \multirow{2}{*}{$\begin{array}{l}\text { 4. Što uzrokuje rak vrata } \\
\text { maternice? }\end{array}$} & točno & $88(88,0)$ \\
\hline & netočno & $12(12,0)$ \\
\hline \multirow{2}{*}{$\begin{array}{l}\text { 5. Koliki je period od infekcije } \\
\text { HIV-om do pojave AIDS-a? }\end{array}$} & točno & $61(61,0)$ \\
\hline & netočno & $39(39,0)$ \\
\hline \multirow{2}{*}{$\begin{array}{l}\text { 6. Može li se zaraziti HPV-om } \\
\text { preko zaštićenog spolnog } \\
\text { odnosa? }\end{array}$} & točno & $63(63,0)$ \\
\hline & netočno & $37(37,0)$ \\
\hline \multirow{2}{*}{ 7. Hepatitis B prenosi se: } & točno & $40(40,0)$ \\
\hline & netočno & $60(60,0)$ \\
\hline \multirow{2}{*}{$\begin{array}{l}\text { 8. Pitanje za djevojke: Papa- } \\
\text { test bi se trebao ponavljati: }\end{array}$} & točno & $47(78,3)$ \\
\hline & netočno & $13(21,7)$ \\
\hline \multirow{2}{*}{$\begin{array}{l}\text { 9. Je li prekinuti snošaj } \\
\text { pouzdana metoda za } \\
\text { sprječavanje neželjene } \\
\text { trudnoće? }\end{array}$} & točno & $100(100,0)$ \\
\hline & netočno & $0(0,0)$ \\
\hline
\end{tabular}


$(60,5 \%)$ ne bi izvršila abortus, dok su muški ispitanici znatno neodlučniji te tek $33,3 \%$ od njih ne bi predlagalo abortus. Većina ispitanika smatra da je abortus ubojstvo (54\%), dok ih se jednak broj protivi toj tvrdnji i nema stav (23\%). Većina ispitanika (65\%) smatra da bi besplatni kontraceptivi smanjili broj neželjenih trudnoća i spolno prenosive bolesti, dok gotovo svi (91\%) smatraju da je zdravstveni odgoj potreban u školama (tablica 4). Analiza razlika u navikama ispitanika prema školi pokazala je šest značajnih razlika. Značajno veći broj ispitanika koji pohađaju medicinsku školu stupio je u spolni odnos $(p=0,002)$. Među ispitanicima koji su imali spolne odnose, značajno veći broj gimnazijalaca nema stalne partnere $(p=0,045)$, češće su imali partnere za jednu noć $(p=0,016)$, češće ne upotrebljavaju kontracepciju $(p=0,025)$. Učenici iz medicinske škole značajno više razgovaraju o spolnim odnosima, dok se gimnazijalci češće informiraju putem interneta i knjiga $(p=0,001)$. Kada govorimo o onima koji razgovaraju o spolnim odnosima, gimnazi-

\begin{tabular}{|c|c|c|}
\hline \multicolumn{2}{|l|}{ STAVOVI } & $\mathrm{N}(\%)$ \\
\hline \multirow{4}{*}{$\begin{array}{l}\text { Pitanje za djevojke: Da sada } \\
\text { zatrudnite, biste li abortirali? }\end{array}$} & $\mathrm{da}$ & $5(13,2)$ \\
\hline & ne & $\begin{array}{c}23 \\
(60,5)\end{array}$ \\
\hline & ne znam & $\begin{array}{c}10 \\
(26,3)\end{array}$ \\
\hline & $\begin{array}{l}\text { ovisi o stavu } \\
\text { roditelja }\end{array}$ & $0(0,0)$ \\
\hline \multirow{4}{*}{$\begin{array}{l}\text { Pitanje za mladiće: Da vaša } \\
\text { djevojka sada zatrudni, biste li } \\
\text { joj predložili da abortira? }\end{array}$} & da & $5(23,8)$ \\
\hline & ne & $7(33,3)$ \\
\hline & ne znam & $8(38,1)$ \\
\hline & $\begin{array}{l}\text { ovisi o stavu } \\
\text { roditelja }\end{array}$ & $1(4,8)$ \\
\hline \multirow{3}{*}{ Je li pobačaj ubojstvo? } & da & $\begin{array}{c}54 \\
(54,0)\end{array}$ \\
\hline & ne & $\begin{array}{c}23 \\
(23,0)\end{array}$ \\
\hline & ne znam & $\begin{array}{c}23 \\
(23,0)\end{array}$ \\
\hline \multirow{2}{*}{$\begin{array}{l}\text { Smatrate li da bi bilo manje } \\
\text { neželjenih trudnoća i osoba } \\
\text { zaraženih spolno prenosivim } \\
\text { bolestima da su kontraceptivi } \\
\text { besplatni? }\end{array}$} & $\mathrm{da}$ & $\begin{array}{c}65 \\
(65,0)\end{array}$ \\
\hline & ne & $\begin{array}{c}35 \\
(35,0)\end{array}$ \\
\hline \multirow{2}{*}{$\begin{array}{l}\text { Smatrate li da je zdravstveni } \\
\text { odgoj potreban u školama? }\end{array}$} & da & $\begin{array}{c}91 \\
(91,0)\end{array}$ \\
\hline & ne & $9(9,0)$ \\
\hline
\end{tabular}

\begin{tabular}{|c|c|c|c|c|}
\hline \multicolumn{2}{|c|}{ NAVIKE } & $\begin{array}{l}\text { Gimnazija } \\
\text { N (\%) }\end{array}$ & $\begin{array}{l}\text { Medicinska } \\
\text { škola }\end{array}$ & $\mathrm{p}^{*}$ \\
\hline \multirow{2}{*}{$\begin{array}{l}\text { 1. Jesi li ikad } \\
\text { imao/la spolni } \\
\text { odnos? }\end{array}$} & $\mathrm{da}$ & $22(44,0)$ & $37(74,0)$ & \multirow{2}{*}{0,002} \\
\hline & ne & $28(56,0)$ & $13(26,0)$ & \\
\hline \multirow{5}{*}{$\begin{array}{l}\text { 2. Razlog stupa- } \\
\text { nja u spolni } \\
\text { odnos bio je: }\end{array}$} & ljubav & $11(50,0)$ & $26(70,3)$ & \multirow{5}{*}{0,220} \\
\hline & $\begin{array}{c}\text { utjecaj } \\
\text { vršnjaka }\end{array}$ & $0(0,0)$ & $1(2,7)$ & \\
\hline & $\begin{array}{l}\text { droga/ } \\
\text { alkohol }\end{array}$ & $3(13,6)$ & $0(0,0)$ & \\
\hline & znatiželja & $8(36,4)$ & $9(24,3)$ & \\
\hline & $\begin{array}{l}\text { nagovor } \\
\text { partnera }\end{array}$ & $0(0,0)$ & $1(2,7)$ & \\
\hline \multirow{2}{*}{$\begin{array}{l}\text { 3. Imaš li stalnog } \\
\text { partnera? }\end{array}$} & da & $9(40,9)$ & $25(67,6)$ & \multirow{2}{*}{0,045} \\
\hline & ne & $13(59,1)$ & $12(32,4)$ & \\
\hline \multirow{2}{*}{$\begin{array}{l}\text { 4. Jesi li ikad } \\
\text { imao/la } \\
\text { „partnera za } \\
\text { jednu noć”? }\end{array}$} & da & $9(40,9)$ & $5(13,5)$ & \multirow[b]{2}{*}{0,016} \\
\hline & ne & $13(59,1)$ & $32(86,5)$ & \\
\hline \multirow{2}{*}{$\begin{array}{l}\text { 5. Jesi li upoznat/a } \\
\text { s dosadašnjim } \\
\text { spolnim } \\
\text { životom svojeg } \\
\text { partnera? }\end{array}$} & da & $14(63,6)$ & $29(78,4)$ & \multirow[b]{2}{*}{0,218} \\
\hline & ne & $8(36,4)$ & $8(21,6)$ & \\
\hline \multirow{5}{*}{$\begin{array}{l}\text { 6. Koje vrste } \\
\text { kontracepcije } \\
\text { upotrebljavate? }\end{array}$} & ne koristim & $4(18,2)$ & $0(0,0)$ & \multirow{5}{*}{0,025} \\
\hline & prezervativ & $15(68,2)$ & $29(78,4)$ & \\
\hline & pilule & $0(0,0)$ & $4(10,8)$ & \\
\hline & $\begin{array}{l}\text { prekinuti } \\
\text { snošaj }\end{array}$ & $2(9,1)$ & $1(2,7)$ & \\
\hline & $\begin{array}{c}\text { više } \\
\text { metoda }\end{array}$ & $1(4,5)$ & $3(8,1)$ & \\
\hline \multirow{2}{*}{$\begin{array}{l}\text { 7. Pitanje za } \\
\text { djevojke: Jesi } \\
\text { li do sada } \\
\text { upotrebljavala } \\
\text { pilule za dan } \\
\text { poslije? }\end{array}$} & da & $0(0,0)$ & $4(14,3)$ & \multirow[b]{2}{*}{0,206} \\
\hline & ne & $10(100,0)$ & $24(85,7)$ & \\
\hline \multirow{3}{*}{$\begin{array}{l}\text { 8. Razgovaraš } \\
\text { li s nekim } \\
\text { o temama } \\
\text { povezanima } \\
\text { sa spolnim } \\
\text { odnosima? }\end{array}$} & da & $25(51,0)$ & $38(76,0)$ & \multirow{3}{*}{0,001} \\
\hline & $\begin{array}{c}\text { informiram } \\
\text { se }\end{array}$ & $22(44,0)$ & $6(12,0)$ & \\
\hline & ne & $3(6,0)$ & $6(12,0)$ & \\
\hline \multirow{5}{*}{$\begin{array}{l}\text { 9. Ako je tvoj } \\
\text { odgovor na } \\
\text { prethodno } \\
\text { pitanje „da”, s } \\
\text { kim razgovaraš o } \\
\text { tim temama? }\end{array}$} & roditelji & $0(0,0)$ & $11(28,9)$ & \multirow{5}{*}{0,006} \\
\hline & brat/sestra & $3(12,0)$ & $7(18,4)$ & \\
\hline & prijatelji & $18(72,0)$ & $12(31,6)$ & \\
\hline & liječnik & $0(0,0)$ & $0(0,0)$ & \\
\hline & partner & $4(16,0)$ & $8(21,1)$ & \\
\hline \multirow{2}{*}{$\begin{array}{l}\text { 10. Pitanjeza } \\
\text { djevojke: Jesi li } \\
\text { do sadabila na } \\
\text { ginekološkom } \\
\text { pregledu? }\end{array}$} & da & $5(25,0)$ & $20(50,0)$ & \multirow[b]{2}{*}{0,064} \\
\hline & ne & $15(75,0)$ & $20(50,0)$ & \\
\hline
\end{tabular}




\section{Tablica 6. Analiza razlika u znanjima ispitanika prema školi}

\begin{tabular}{|c|c|c|c|c|}
\hline \multicolumn{2}{|l|}{ ZNANJE } & $\begin{array}{l}\text { Gimnazija } \\
\mathrm{N}(\%)\end{array}$ & $\begin{array}{c}\text { Medicinska } \\
\text { škola } \\
\text { N (\%) }\end{array}$ & $p^{*}$ \\
\hline \multirow{2}{*}{$\begin{array}{l}\text { 1. Štiti li hormonska kontracepcija od spolno } \\
\text { prenosivih bolesti? }\end{array}$} & točno & $46(92,0)$ & $47(94,0)$ & \multirow{2}{*}{0,695} \\
\hline & netočno & $4(8,0)$ & $3(6,0)$ & \\
\hline \multirow{2}{*}{$\begin{array}{l}\text { 2. Štiti li prezervativ } 100 \% \text { od spolno prenosivih } \\
\text { bolesti? }\end{array}$} & točno & $41(82,0)$ & $46(92,0)$ & \multirow{2}{*}{0,137} \\
\hline & netočno & $9(18,0)$ & $4(8,0)$ & \\
\hline \multirow{2}{*}{ 3. HIV se može prenijeti: } & točno & $35(70,0)$ & $41(82,0)$ & \multirow{2}{*}{0,160} \\
\hline & netočno & $15(30,0)$ & $9(18,0)$ & \\
\hline \multirow{2}{*}{ 4. Što uzrokuje rak vrata maternice? } & točno & $39(78,0)$ & $49(98,0)$ & \multirow{2}{*}{$\underline{0,002}$} \\
\hline & netočno & $11(22,0)$ & $1(2,0)$ & \\
\hline \multirow{2}{*}{$\begin{array}{l}\text { 5. Koliki je period od infekcije HIV-om do pojave } \\
\text { AIDS-a? }\end{array}$} & točno & $12(24,0)$ & $49(98,0)$ & \multirow{2}{*}{$\underline{0,035}$} \\
\hline & netočno & $38(76,0)$ & $1(2,0)$ & \\
\hline \multirow{2}{*}{$\begin{array}{l}\text { 6. Može li se zaraziti HPV-om preko zaštićenog } \\
\text { spolnog odnosa? }\end{array}$} & točno & $29(58,0)$ & $34(68,0)$ & \multirow{2}{*}{0,300} \\
\hline & netočno & $21(42,0)$ & $16(32,0)$ & \\
\hline \multirow{2}{*}{ 7. Hepatitis B prenosi se: } & točno & $15(30,0)$ & $25(50,0)$ & \multirow{2}{*}{$\underline{0,041}$} \\
\hline & netočno & $35(70,0)$ & $25(50,0)$ & \\
\hline \multirow{2}{*}{$\begin{array}{l}\text { 8. Pitanje za djevojke: Papa-test bi se trebao } \\
\text { ponavljati: }\end{array}$} & točno & $13(65,0)$ & $34(85,0)$ & \multirow{2}{*}{0,076} \\
\hline & netočno & $7(35,0)$ & $6(15,0)$ & \\
\hline \multirow{2}{*}{$\begin{array}{l}\text { 9. Je li prekinuti snošaj pouzdana metoda za } \\
\text { sprječavanje neželjene trudnoće? }\end{array}$} & točno & $50(100,0)$ & $50(100,0)$ & \multirow{2}{*}{0,152} \\
\hline & netočno & $0(0,0)$ & $0(0,0)$ & \\
\hline
\end{tabular}

* Hi-kvadrat test

\section{Tablica 7. Analiza razlika u stavovima ispitanika prema školi}

\begin{tabular}{|c|c|c|c|c|}
\hline \multicolumn{2}{|c|}{ STAVOVI } & $\begin{array}{l}\text { Gimnazija } \\
\mathrm{N}(\%)\end{array}$ & $\begin{array}{l}\text { Medicinska } \\
\text { škola } \\
\text { N (\%) }\end{array}$ & $p^{*}$ \\
\hline \multirow{4}{*}{$\begin{array}{l}\text { 1. Pitanje za djevojke: Da sada zatrudnite, } \\
\text { biste li abortirali? }\end{array}$} & $\mathrm{da}$ & $4(40,0)$ & $1(3,6)$ & \multirow{4}{*}{$\underline{0,002}$} \\
\hline & ne & $2(20,0)$ & $21(75,0)$ & \\
\hline & ne znam & $4(40,0)$ & $6(21,4)$ & \\
\hline & ovisi o stavu roditelja & $0(0,0)$ & $0(0,0)$ & \\
\hline \multirow{4}{*}{$\begin{array}{l}\text { 2. Pitanje za mladiće: Da vaša djevojka } \\
\text { sada zatrudni, biste li joj predložili da } \\
\text { abortira? }\end{array}$} & da & $4(33,3)$ & $1(11,1)$ & \multirow{4}{*}{$\underline{0,043}$} \\
\hline & ne & $1(8,3)$ & $6(66,7)$ & \\
\hline & ne znam & $6(50,0)$ & $2(22,2)$ & \\
\hline & ovisi o stavu roditelja & $1(8,3)$ & $0(0,0)$ & \\
\hline \multirow{3}{*}{ 3. Je li pobačaj ubojstvo? } & da & $22(44,0)$ & $32(64,0)$ & \multirow{3}{*}{$\underline{0,008}$} \\
\hline & ne & $18(36,0)$ & $5(10,0)$ & \\
\hline & ne znam & $10(20,0)$ & $13(26,0)$ & \\
\hline \multirow{2}{*}{$\begin{array}{l}\text { 4. Bi li bilo manje neželjenih trudnoća } \\
\text { i spolnih bolesti da su kontraceptivi } \\
\text { besplatni? }\end{array}$} & da & $33(66,0)$ & $32(64,0)$ & \multirow[b]{2}{*}{0,833} \\
\hline & ne & $17(34,0)$ & $18(36,0)$ & \\
\hline \multirow{2}{*}{$\begin{array}{l}\text { 5. Smatrate li da je zdravstveni odgoj } \\
\text { potreban u školama? }\end{array}$} & da & $45(90,0)$ & $46(92,0)$ & \multirow{2}{*}{0,726} \\
\hline & ne & $5(10,0)$ & $4(8,0)$ & \\
\hline
\end{tabular}

* Hi-kvadrat test 
jalci češće razgovaraju s prijateljima, a medicinari češće $s$ roditeljima $(p=0,006)$ (tablica 5$)$. Analiza razlika u znanjima ispitanika prema školi pokazala je tri statistički značajne razlike. Ispitanici iz medicinske škole pokazali su značajno veću razinu znanja u pitanjima povezanima s uzrokom raka vrata maternice $(p=0,002)$, periodom od infekcije HIV-om do pojave AIDS-a $(p=0,035)$ te metodama prijenosa hepatitisa $B(p=0,041)$ (tablica 6$)$. Analiza razlika u stavovima ispitanika prema školi pokazala je također tri statistički značajne razlike. Značajno veći broj ženskih i muških ispitanika koji pohađaju gimnaziju odlučio bi se na pobačaj u slučaju trudnoće $(p=0,002 ; p=0,043)$, dok značajno veći broj učenika medicinske škole pobačaj smatra ubojstvom $(p=0,008)$ (tablica 7).

\section{Rasprava}

Ljudska spolnost prihvaćena je kao neizmjerno složeno područje koje uključuje somatske, emocionalne, intelektualne i socijalne aspekte pojedinca. Seksualno zdravlje može se postići pozitivnom integracijom ovih osobnih karakteristika, što rezultira uspješnim izražavanjem seksualne prirode. U razdoblju adolescencije mladi se pripremaju za izgradnju svoje individualnosti kako bi prerasli u zdravu odraslu osobu koja integrira psihološka, socijalna i fizička iskustva, a to je i razdoblje kada strukturiraju svoje rodne uloge, seksualne stavove i seksualno ponašanje. ${ }^{16-19}$

Rano započinjanje seksualne aktivnosti povezano je s više seksualnih partnera, neupotrebljavanjem kondoma, spolnim bolestima i trudnoćom tijekom adolescencije. ${ }^{20,} 21$ Većina adolescenata započinje seksualne aktivnosti tijekom srednje škole. ${ }^{21,22}$ Kako bi procijenio jesu li se posljednjih godina dogodile promjene u udjelu srednjoškolaca koji su imali spolne odnose, Centar za kontrolu i prevenciju bolesti (Centers for Disease Control and Prevention) ispitao je ukupne trendove među srednjoškolcima u SAD-u, koristeći se podacima nacionalne ankete o rizičnom ponašanju mladih i podacima iz 29 država. Udio srednjoškolaca u SAD-u koji su imali spolne odnose nije se znatno promijenio tijekom razdoblja od 1995. do 2005. (53,1 \% do 46,8 \%). U cijeloj je zemlji tijekom razdoblja od 2005. do 2015. utvrđeno znatno linearno smanjenje prevalencije spolnih odnosa među svim učenicima (46,8 \% do 41,2 \%). Znatno linearno smanjenje također je utvrđeno među učenicima muškog spola (47,9 \% do $43,2 \%)$, i ženskog spola ( $45,7 \%$ do $39,2 \%) .{ }^{22}$ lako se ovi nalazi ne mogu izravno povezati ni s jednom konkretnom intervencijom, rezultati ukazuju da se među srednjoškolcima u SAD-u dogodilo smanjenje prevalencije spolnih odnosa. Tijekom razdoblja od 2005. do 2015. Sjedinjene Američke Države doživjele su znatne pomake u različitim čimbenicima koji su mogli utjecati na ova otkrića, uključujući promjene u tehnologiji i u tome koliko mladi upotrebljavaju društvene medije, potrebe i financiranje obrazovanja te inovacije i savezne resurse za prevenciju spolnih bolesti i tinejdžerskih trudnoća. ${ }^{23} \mathrm{U}$ našem je istraživanju udio srednjoškolaca koji su stupili u spolni odnos znatno veći i iznosi 59 \%. Pritom je gotovo četvrtina stupila u spolni odnos „na jednu noć”. Uz to, većina ispitanika navodi kako je upoznata s partnerovim spolnim životom te gotovo svi primjenjuju neku od kontracepcijskih metoda. Učestalost stupanja u spolne odnose češća je među ispitanicima medicinske škole, ali je među njima češći i razgovor o spolnom životu. Među gimnazijalcima znatno je češći seks za jednu noć, izbjegavanje upotrebe kontracepcije te informiranje putem interneta. Takve navike govore nam da je potrebno dodatno poraditi na obrazovanju mladih, možda i preuzeti pozitivne primjere iz navedenog slučaja iz SAD-a. U prilog tome govori i istraživanje iz 2015. provedeno među učenicima iz Biograda na Moru. ${ }^{14} \mathrm{U}$ tom je istraživanju bilo tek $38 \%$ spolno aktivnih ispitanika, što očito pokazuje porast nakon toga. Za usporedbu naših ispitanika i ispitanika iz Biograda, većina naših ispitanika (62 \%) u spolni je odnos stupila iz ljubavi, dok je među ispitanicima iz drugog istraživanja taj postotak bio niži (45\%). Nasuprot tome, znatno je veći broj ispitanika u drugom istraživanju tijekom prvog spolnog odnosa bio pod utjecajem droge/alkohola (23 \%) nego među našim ispitanicima (5,1\%). Nadalje, ispitanici se razlikuju i po tome što većina u ovom istraživanju ima stalnog partnera, dok u drugoj skupini većina nema stalnog partnera. Kao što je općepoznato, promiskuitetno ponašanje vrlo je rizično, zbog vrlo lakog prenošenja spolnih bolesti. Pozitivno je to što većina ispitanika u oba istraživanja primjenjuje kontracepcijske metode, i to najčešće upotrebljavaju prezervativ, što može uvelike doprinijeti sprječavanju zaraze. U oba slučaja većina ispitanika o temama povezanima sa spolnim odnosima razgovara s prijateljima. ${ }^{25}$ 
Sveukupno smanjenje prevalencije spolnih odnosa tijekom razdoblja od 2005. do 2015. u SAD-u pozitivna je promjena seksualnog rizika kod adolescenata (tj. ponašanja zbog kojih su izloženi riziku spolno prenosivih bolesti ili trudnoće). Smanjenje broja spolnih odnosa po razredima sugerira da je sve manje učenika seksualno aktivno tijekom ranijih godina srednje škole te je ovaj je nalaz posebno ohrabrujući. Adolescenciju karakterizira dubok intelektualni, emocionalni i psihološki rast, na što bi sve mogle utjecati sociokulturne i obrazovne promjene..$^{23} \mathrm{U}$ slično istraživanje Tubelja i Sambolec uključili su učenike drugih i četvrtih razreda strukovne škole i gimnazije. Rezultati ukazuju kako su učenici strukovnih škola spolno aktivniji od gimnazijalaca. Svoje rezultate uspoređivali su s istraživanjima provedenima u ostalim dijelovima Republike Hrvatske. ${ }^{24}$ Osim češće spolne aktivnosti, među strukovnim školama nalazi se da su djevojke spolno aktivnije i češće mijenjaju partnere. Također, ukazuje se na nedostatak edukacije i poznavanja metoda prevencije rizičnih ponašanja. U skladu s time, djevojke ne samo da češće mijenjaju partnere nego je prema rezultatima vidljivo $\mathrm{i}$ da za partnera odabiru mladiće starije od sebe. Jedna od poražavajućih činjenica jest ta da čak $20 \%$ ispitanika istraživanja tijekom spolnog odnosa ne upotrebljava zaštitu. ${ }^{24} \mathrm{U}$ svojem istraživanju Kim i suradnici su istraživali seksualne navike, stavove i znanja o kontracepciji među muškim srednjoškolcima u Koreji. ${ }^{25}$ Rezultati su otkrili da su znanja o seksualnosti i kontracepciji bila vrlo loša te je bilo potrebno uložiti znatan napor u promjeni njihovih seksualnih stavova, koji su slični nalazima prethodnih studija. ${ }^{26,27}$ To pokazuje da trenutačni seksualni odgoj u školama nije dovoljno učinkovit, ne samo kod nas, i potrebno je osigurati sustavne programe spolnog obrazovanja koji mogu pridonijeti izgradnji kvalitetnoga seksualnog znanja te zdravih navika i stavova srednjoškolaca.

Općenito, adolescenti u dobi od 15 do 17 godina pokazali su nisku razinu spolnog znanja, posebno s obzirom na kontrolu rađanja, spolno prenosive bolesti i vjerojatnost trudnoće. ${ }^{28-31}$ Još jedna provedena studija u Koreji izvijestila je da je stopa spolnih odnosa između 13 i 18 godina bila $5,2 \%$, a u ovom istraživanju iznosila je $16,5 \%$. Ovaj je rezultat ukazao na to da su se seksualna iskustva povećala tijekom srednjoškolskog razdoblja i vrlo je važno pružiti kvalitetno seksualno obrazovanje, posebno srednjoškolcima. ${ }^{30}$ Rezultati istraživanja pokazali su da je prosjek seksualnog znanja ispitanika bio 12,18 od ukupno 30 bodova, najmanje 0 bodova, a najviše 26 bodova. Odgovore na 11 od 30 pitanja znalo je $50 \%$ ili više ispitanika. Sveukupno, znanje ispitanika bilo je loše, a pitanja na koje je bilo manje od $10 \%$ točnih odgovora bila su tvrdnje „Muškarci ne mogu doživjeti orgazam nakon vazektomije” (8,9 \%) i „Uzimanje antibiotika prije ili nakon odnosa može spriječiti spolne bolesti" (8,9\%). Kimova studija otkrila je da je prosjek znanja o kontracepciji među ispitanicima bio 1,56 od 15. Ispitanici su bili vrlo slabo informirani o kontracepciji i samo je manje od $30 \%$ ispitanika točno odgovorilo na svih 15 pitanja koja se odnose na znanje o kontracepciji. ${ }^{25}$ Znanje naših ispitanika također je bilo na zabrinjavajućoj razini. Manje od petine ispitanika znalo je sve točne odgovore, dok ih je $80 \%$ imalo do četiri greške od devet pitanja. Pojedini ispitanici imali su i sedam netočnih odgovora. Najlošija razina znanja bila je povezana s prijenosom spolnih bolesti, što je vrlo zabrinjavajuće. Kada govorimo o razlikama među školama, očekivano ispitanici iz medicinske škole imaju znatno veću razinu znanja od kolega iz gimnazije. ${ }^{24}$ Slično se može zaključiti i među našim ispitanicima, ali je velik problem u oba istraživanja to što učenici nisu pokazali visoku razinu znanja o prenošenju spolnih bolesti. Upozoravajući je podatak da većina učenica nikad nije bila kod ginekologa, a preporučuje se da se prvi ginekološki pregled svakako napravi prije početka spolnih odnosa. $U$ radu „Zaštita reproduktivnog zdravlja mladih - modeli prevencije" autori iznose kako je 2007. učinjeno 250 ginekoloških pregleda djevojaka uključujući citološku analizu, test na Chlamydiju i ultrazvuk. Rezultati pregleda su zabrinjavajući, pronađeno je 25 djevojaka s CIN-om I, šest djevojaka s CIN-om II, 12 s ASCUS-om, u 22 djevojke i pet mladića izolirana je Chlamydia trachomatis, a sedam djevojaka pozitivno je na HPV. ${ }^{32}$ Još jedno u nizu istraživanja s poražavajućim rezultatima provedeno je uspoređivanjem navika i stavova te razlika između medicinske škole u Splitu te nezdravstvenih škola u Bjelovaru i Našicama, gdje je 130 srednjoškolaca također pokazalo nedovoljno znanje o spolnosti, menstruacijskom ciklusu, kontracepciji i spolno prenosivim bolestima. ${ }^{33}$

Ovo je istraživanje pokazalo da su seksualni stavovi ispitanika bili pozitivni. Među pitanjima povezanima sa seksualnim stavovima, stavke koje su pokazale rezultate ispod prosjeka bile su sljedeće; 36,7 \% ispitanika navelo je da je moguć „seks s osobom koju ne volim”, 45,6 \% je izjavilo da se „seks može naučiti bez obrazovanja”, a 39,2 \% je izjavilo da „muškarci imaju jaču seksualnu želju od žena”. Stoga je tinejdžerima potrebno pružiti odgovarajuće znanje koje može promijeniti njihove stavove. I među našim ispitanicima stavovi su bili pretežno pozitivni. Djevojke su bile znatno odlučnije u 
izbjegavanju abortusa. Osim toga, gotovo svi ispitanici smatraju da je zdravstveni odgoj potreban u školama. S obzirom na takve stavove mladih, potrebno je poduzeti neke konkretne mjere da bi im se omogućila bolja informiranost i dostupnije kvalitetnije obrazovanje. Velika razlika u stavovima ispitanika vidljiva je među školama. Medicinari imaju znatno izraženiji negativan stav prema pobačaju, dok ga gimnazijalci znatno više zagovaraju. Ta razlika vjerojatno može biti pojašnjena navedenim razlikama u znanju koje govore u korist medicinara. Također su u Biogradskom istraživanju, kao i u mnogim drugima, učenice pokazale veću spremnost za zadržavanje djeteta u slučaju da se dogodi trudnoća nego učenici. Čak $85 \%$ učenica i $50 \%$ učenika se izjavilo je da je pobačaj ubojstvo. Uz to, $48 \%$ učenika smatra da je zdravstveni odgoj potreban u školama, dok ih $49 \%$ smatra da nije..$^{14,24}$

Mnogi su istraživači otkrili da stav prema seksu ima ogroman utjecaj na seksualne aktivnosti. lako je nekoliko studija otkrilo da viši nivoi znanja ne sprječavaju nužno mlade ljude u rizičnom seksualnom ponašanju, unatoč tome, dobro znanje pruža osnovu mladim ljudima da donose utemeljene odluke povezane sa svojim seksualnim životom (posebno prije nego što postanu seksualno aktivni), a tako i reproduktivnim i općim zdravljem u cjelini. ${ }^{32,33,34}$

\section{Zaključci}

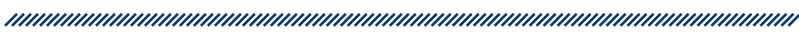

Ovim istraživanjem utvrđeno je:

- Većina ispitanika stupila je u spolne odnose tijekom srednje škole, češće oni iz medicinske škole.

- Najčešći je razlog stupanja u spolni odnos ljubav.

- Većina ispitanika ima stalnog spolnog partnera i upoznata je s njegovim spolnim životom, češće oni iz medicinske škole.

- Gotovo svi ispitanici upotrebljavaju kontracepciju.

- Ispitanici iz gimnazije češće izbjegavaju upotrebu kontracepcije.

- Znanje ispitanika o spolnosti na nezadovoljavajućoj je razini.

- Bolje znanje o spolnosti pokazali su ispitanici iz medicinske škole.

- Ispitanici ne znaju dovoljno o spolnim bolestima.

- Ispitanice imaju znatno jasnije stavove protiv abortusa od muških ispitanika.

- Gimnazijalci češće zagovaraju pobačaj.

- Većina ispitanika želi zdravstveni odgoj u školama.

Nužno je osmisliti i u sve škole, od najranije dobi, uvesti kvalitetne programe odgoja i obrazovanja za zdravlje, s posebnim naglaskom na odgovorno spolno ponašanje, spolnu i rodnu ravnopravnost te zaštitu spolnog i reproduktivnog zdravlja. 


\section{Referencije}

1. Sessa FM. Adolescence. U: Friedman HS, ur. Encyclopedia of Mental Health. Second Edition. Academic Press Elsevier, 2016; 7: 11-19.

2. Cauffman E, Steinberg L. (Im)maturity of judgment in adolescence: Why adolescents may be less culpable than adults. Behavioral sciences \& the law. 2000; 18: 741-760.

3. Maswikwa B, Richter L, Kaufman J, Nandi A. Minimum Marriage Age Laws and the Prevalence Of Child Marriage and Adolescent Birth: Evidence from Sub-Saharan Africa. International Perspectives on Sexual and Reproductive Health. 2015; 41: 58.

4. Johnson KA, Tyler KA. Adolescent Sexual Onset: An Intergenerational Analysis. J Youth Adolescence. 2007; 36: 939-949.

5. Girma S, Paton D. Is education the best contraception: The case of teenage pregnancy in England? Social Science \& Medicine. 2015; 131: 1-9.

6. Pringle J, Mills KL, McAteer J, Jepson R, Hogg E, Anand $\mathrm{N}$, et al. The physiology of adolescent sexual behaviour: A systematic review. Cogent Social Sciences. 2017; 20: 3-5.

7. Geronimus AT. Damned if you do: Culture, identity, privilege, and teenage childbearing in the United States. Social science \& medicine. 2003; 57: 881-893.

8. Wakschlag LS, Hans SL. Early parenthood in context: Implications for development and intervention. Elsavier. 2000; 5: 8-13.

9. Coyne CA, D’Onofrio BM. Some (But Not Much) Progress Toward Understanding Teenage Childbearing. Elsevier; 2012; 8: 52-113.

10. Sher DJ. Missed periods: Scotland's opportunities for better pregnancies, healthier parents and thriving babies the first time... and every time. Elsevier. 2016; 15: 77-83.

11. Windle M, Sales JM, Windle RC. Influence of alcohol and illicit drug use on sexual behavior. Handbook of child and adolescent sexuality. 2013; 9: 253-274.

12. Donovan JE, Jessor R, Costa FM. Adolescent health behavior and conventionality-unconventionality: An extension of problem-behavior therapy. Health Psychology. 1991; 10: 52.

13. Lonczak HS, Abbott RD, Hawkins JD, Kosterman R, Catalano RF. Effects of the Seattle Social Development Project on sexual behavior, pregnancy, birth, and sexually transmitted disease outcomes by age 21 years. Archives of pediatrics \& adolescent medicine. 2002; 156: 438-447.

14. Petani R, Vulin A. Spolno ponašanje adolescenata, njihova informiranost i mišljenje o seksualnosti. Acta ladertina. 2018; 15 (1): 35-58.

15. Huić M, Marušić A. Medicina utemeljena na dokazima. U: Marušić M, ur. Uvod u znanstveni rad u medicini. 2013; 5: 229-245.

16. Harrison K, Hefner V. Media exposure, current and future body ideals, and disordered eating among preadolescent girls: A longitudinal panel study. Journal of Youth and Adolescence. 2006; 35: 146-156.

17. Slater MD. Reinforcing spirals: The mutual influence of media selectivity and media effects and their impact on individual behavior and social identity. Communication theory. 2007; 17: 281-303.

18. Brown JD. Adolescents' sexual media diets. Journal of adolescent health. 2000; 27: 35-40.

19. Cha $\mathrm{N}-\mathrm{H}$, Wang M-J. Actual state of recognition and experience of love, sex knowledge and self-esteem in girl's middle and high school students. Korean Journal of Women Health Nursing. 2006; 12: 249-256.

20. Heywood W, Patrick K, Smith AMA, Pitts MK. Associations Between Early First Sexual Intercourse and Later Sexual and Reproductive Outcomes: A Systematic Review of Population-Based Data. Arch Sex Behav. 2015; 44: 531-569.

21. Kaestle CE. Young Age at First Sexual Intercourse and Sexually Transmitted Infections in Adolescents and Young Adults. American Journal of Epidemiology. 2005; 161: 774-780.

22. Ethier KA, Kann L, McManus T. Sexual intercourse among high school students - 29 states and United States Overall, 2005-2015. MMWR Morbidity and Mortality Weekly Report. 2018; 66: 1393.

23. Giedd JN. The Digital Revolution and Adolescent Brain Evolution. Journal of Adolescent Health. 2012; 51: 101-105.

24. Trubelja M, Sambolec M. Spolno ponašanje adolescenata - usporedba drugih i četvrtih razreda strukovne škole i gimnazije. Sestrinski glasnik. 2018; 23 (1): 18-22.

25. Kim M-H. Factors affecting Sexual Attitudes among Male High School Students in Korea. IJBSBT. 2016; 8: 149-158.

26. Cooper ML. Alcohol use and risky sexual behavior among college students and youth: evaluating the evidence. Journal of Studies on Alcohol, supplement. 2002; 14: 101-117.

27. Herek GM. The psychology of sexual prejudice. Current directions in psychological science. 2000; 9: 19-22. 
28. Yip PS, Zhang H, Lam T-H, Lam KF, Lee AM, Chan J, et al. Sex knowledge, attitudes, and high-risk sexual behaviors among unmarried youth in Hong Kong. BMC public health. 2013; 13: 691.

29. Ip W-Y, Chau JP, Chang AM, Lui MH. Knowledge of and attitudes toward sex among Chinese adolescents. Western Journal of Nursing Research. 2001; 23: 211-223.

30. Lee IS, Choi GY, Cha SH, Park HY, Lee JJ. A survey on the sexual behavior of adolescents in South Korea: The third survey in 2007. Korean Journal of Obstetrics \& Gynecology. 2010; 53: 512-519.

31. Agius PA, Pitts MK, Smith AM, Mitchell A. Sexual behaviour and related knowledge among a representative sample of secondary school students between 1997 and 2008. Australian and New Zealand journal of public health. 2010; 34: 476-481.

32. Dabo J, Malatestinić $Đ$, Janković S, Bolf Malović M, Kosanović V. Zaštita reproduktivnog zdravlja mladih. Medicina Fluminensis. 2008; 44: 72-79.

33. Filipović T, Puharić Z, Puharić D, Gašić M. Attitudes and Knowledge of Students on Sexuality in Three Secondary Schools. Croatian Nursing Journal. 2020: 4 (2): 157-164.

34. Koporčić V. Navike, znanje i stavovi o spolnosti adolescenata Brodsko-posavske županije [završni rad]. Pula: Sveučilište Jurja Dobrile u Puli, 2021. 


\section{HABITS, KNOWLEDGE AND ATTITUDES ABOUT SEXUALITY OF ADOLESCENTS IN BRODSKO-POSAVSKA COUNTY}

\author{
1,2 Valentina Koporčić \\ 2,3 Željko Jovanović \\ 1 Opća bolnica Pula \\ 2 Sveučilište Jurja Dobrile u Puli, Medicinski fakultet, \\ studij sestrinstva \\ 3 Sveučilište u Rijeci, Fakultet zdravstvenih studija
}

\section{Abstract}

Aim: Adolescence is a developmental phase during which individuals begin to strengthen their sense of identity, which is marked by autonomous functioning that will lead to sexual maturation and independent living while maintaining secure connections with family, peers and the wider community. The aim of the study is to examine and compare knowledge, attitudes, and habits about adolescent sexuality, and to determine whether there are differences depending on whether the students are from medical high schools or generaleducation secondary schools.

Subjects and methods: The subjects who participated in the study, aged between 17 and 20, were students from two high schools in Slavonski Brod, the Medical High School and the general-education secondary school "Matija Mesić". 100 students participated: 72 females and 28 males. The participants were asked to fill in an anonymous questionnaire containing general questions and questions about their habits, knowledge, and attitudes related to sexual health. Their knowledge was tested through questions about STDs, protection during sexual intercourse, and how often they should be tested. The section on attitudes towards sexuality revolved around the question of attitudes about abortion and whether they believe that sex education is needed in schools.

Results: The analysis of the respondents' habits showed that $59 \%$ of the respondents have had sexual intercourse. Only $17 \%$ of the respondents provided all correct answers, and $80 \%$ of them provided more than half of the correct answers. The majority of the respondents (65\%) believe that free contraceptives would reduce the number of unwanted pregnancies and STDs, while almost all (91\%) believe that sex education is needed in schools.

Conclusion: Most of the respondents have entered into sexual relationships, and the majority of those who have is from the medical school. The most common reason given for entering into the relationship is love. Almost all respondents use contraception. The respondents' knowledge of sex is unsatisfactory, especially of those from the general-education secondary school. More of the female respondents were against abortion than male respondents. Most respondents want sex education in schools.

Key words: adolescents, attitudes, habits, knowledge, sexuality 